Ann. Biol. anim. Bioch. Biophys., I975, 15 (2), 205-214.

\title{
DETERMINATION OF THE MOMENT OF OVULATION IN EWE AND SOW. INFLUENCE OF ENVIRONMENT AND HORMONAL TREATMENT
}

\author{
J. P. SIGNORET and Y. COGNIE \\ Station de Physiologie de la Reproduction, \\ Centre de Recherches de Tours, I. N. R. A., \\ 37380 Nouzilly (France)
}

\begin{abstract}
SUMMARY
In ewe, ovulation occurs 32.0 hours after onset of estrus, and is not significantly modified by control with intravaginal FGA. Injection of PMSG, however, results in earlier onset of estrus in FGA-treated ewes (30 hours vs 37 hours after FGA sponge withdrawal), and an acceleration of LH surge ( $45 \cdot 4$ hours vs 49 hours after FGA sponge withdrawal).

During seasonal anestrus, the physiological state of the female (lactating vs dry) has an influence on response to FGA plus PMSG : onset of estrus is delayed in lactating ewes $(36.7$ hours vs. 33.9 hours after FGA sponge withdrawal). LH peak tends to appear later in lactating ewes, and the ovulation times are more widely spaced as compared to dry controls.

The permanent presence of the male accelerates time of LH surge and ovulation by 6-8 hours, and reduces markedly the duration of sexual receptivity.

In sow, the beginning of ovulation is observed at an average of 38.47 hours, and its termination at 42.27 hours, after onset of estrus. When controlled with methallibure and PMSG, ovulation is delayed, but terminates very rapidly ( 43.34 and 43.57 hours, respectively, after onset of estrus for the beginning and end of ovulation.

Double mating at spontaneous estrus results in earlier and shorter ovulation time (34.ro and 35.0 hours after onset of estrus for the beginning and end of ovulation). The continuous presence of the male reduces the duration of sexual receptivity.
\end{abstract}

The onset of sexual receptivity is generally taken in the practise as the reference point to determine the time for artificial insemination. In the early development of this technique, a number of experiments were designed to determine the pregnancy rates resulting from insemination performed at various times after the onset of behavioral estrus.

The development of methods of ovulation control constitutes an interference in the physiological events of the estrous cycle, and such techniques make it possible to inseminate at a predetermined time without estrus detection, eliminating any 
contact between the male and the female. Timing of the events resulting in ovulation may thus be modified, and these changes could account for some of the variations in pregnancy rates observed after estrus control.

The aim of this report is to review the experimental work done at the Station de Physiologie de la Reproduction of the I. N. R. A. (Nouzilly) to determine the effect of environmental and hormonal factors on the time of ovulation in ewe and sow.

\section{I. 一 EWE}

The occurrence of ovulation was determined by coelioscopic examination of the ovaries (ThImonier and MaulÉon, I969), and behavioral estrus was assessed by presentation at 4 -hour intervals to teaser rams (MAULÉON and DAUZIER, I965). The time of the $\mathrm{LH}$ surge was determined by radioimmunoassay in the blood plasma obtained at 2 or 4 -hour intervals by jugular venipuncture (PELLETIER et al., I968).

The statistical analysis was done after probit transformation (FINNEY, I962). Ovulation was controlled by the use of vaginal pessaries impregnated with fluorogestone acetate (Robinson, I965) associated or not with PMSG (Thrmonier et al., I968).

\section{A. - Time of ovulation during normal estrous cycle}

(CoGNí́ et al., 1970)

During spontaneous estrus, no ewe was observed to have ovulated within 20 hours after the onset of sexual receptivity. The probit analysis of cumulative percentages gives $32.0 \pm 0.80$ hours after onset of estrus as the average time of ovulation (fig. I).

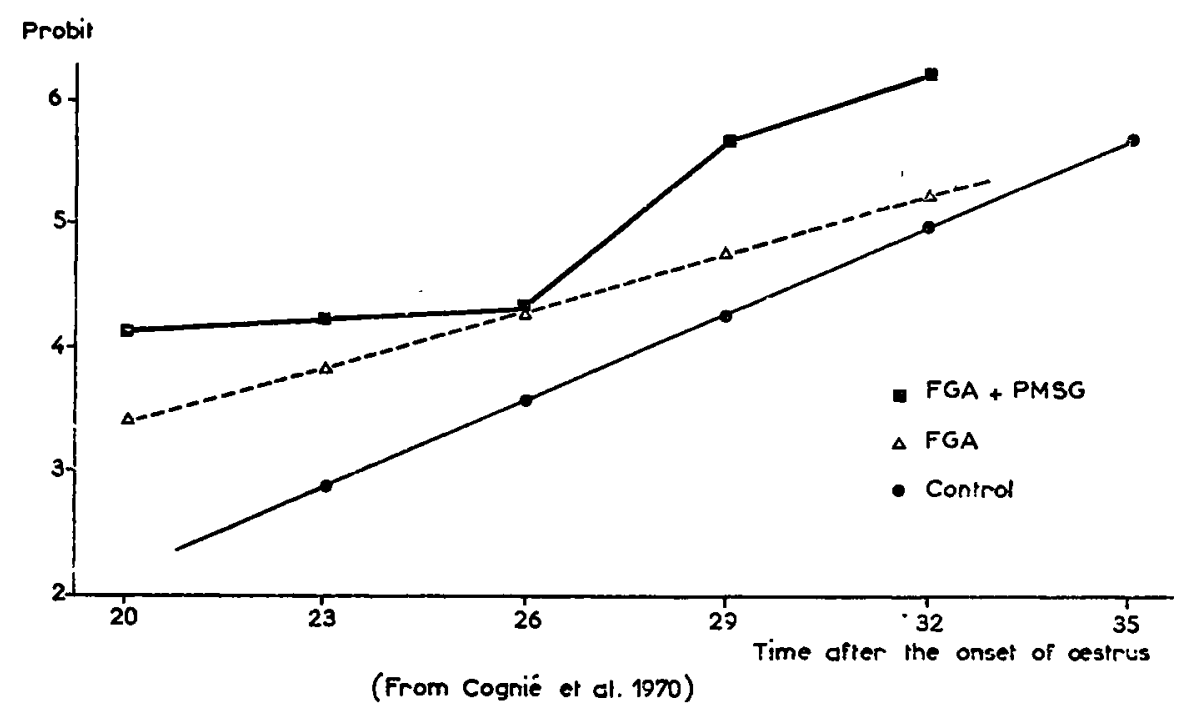

FIG. I. - Ovulation in relation to the onset of oestrus in the ewe Effect of FGA and PMSG 


\section{B. - Effect of progestagen control of ovulation associated or not with PMSG (CoGNié et al., I970)}

When the ewes are treated by progestagen only $(40 \mathrm{mg}$ of fluorogestone acetate(FGA) on a vaginal sponge for $I_{4}$ days), the average ovulation time is not statistically significantly different from that observed in untreated control ewes (30.4 \pm I.33 hours after onset of estrus). However, after PMSG injection at the time of vaginal sponge removal, linear adjustment of the probits is no longer possible $\left(\mathrm{X}^{2}=7.32\right.$, fig. I $)$. An heterogeneity anpears in the responses observed after PMSG : ovulation occurs very early in some 20 p. Ioo of the experimental subjects (within 20 hours after onset of estrus). Probit analysis is possible for the other subjects, and ovulation takes place at a time similar to the untreated control females and those not receiving PMSG (29.8 10.49 hours after onset of estrus).

The time of $L H$ surge was determined after FGA treatment with or without PMSG (PEILETIER and Thimonier, I969). To prevent possible influence of the presence of the ram, we did not check estrus in this experiment. The results (fig. 2)

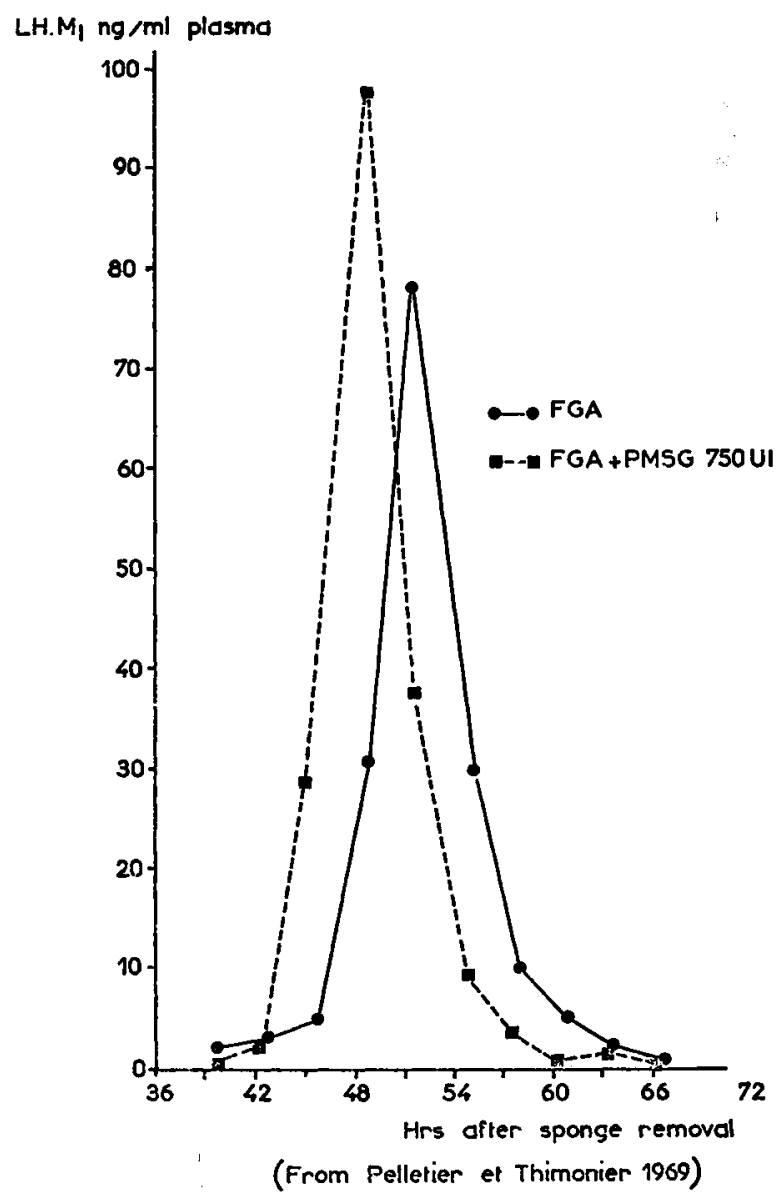

FIG. 2. - LH surge in FGA-treated ewes Effect of PMSG 
indicate that LH surge takes place between 40 and 60 hours after treatment with FGA, the peak of plasma LH occurring earlier in the subjects injected with PMSG. The difference ( 45.5 versus 49 hours after vaginal sponge removal) is statistically significant. A similar effect of PMSG was observed by CoGNiÉ et al., (I970) on the interval between the end of progestagen treatment and the onset of estrus ( 3 I. $4 \pm 0.56$ vs $39.9 \pm 0,90$ hours after vaginal sponge removal) (fig. 3).
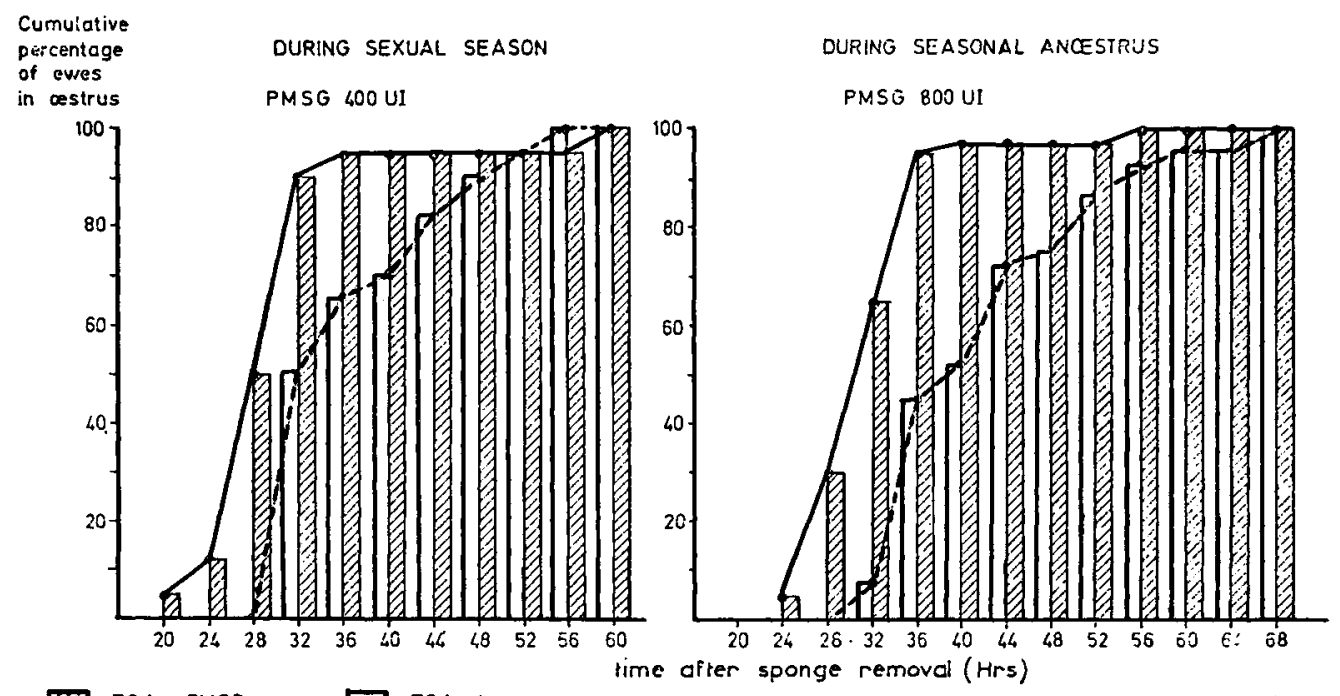

FGA + PMSG

$\square$ FGA alone

(From Cognië et al. 1970)

Fig. 3. - Occurrence of oestrus after FGA associated or not with P.MS(i Effect of the season

\section{C. - Effect of season (CoGNIÉ et al., I970)}

The percentage of ewes behaviorally in estrus is higher after FGA treatment during the sexual season as compared with seasonal anestrus (CoGNí, et al., I970) ; the delay between vaginal sponge withdrawal and onset of estrus is shorter during the sexual season (fig. 3). However, the moment of ovulation after onset of sexual receptivity is not modified.

\section{D. - Effect of lactation (CogNiÉ, to be published)}

When ovulation is induced by FGA and PMSG during seasonal anestrus in lactating ewes, the pregnancy rates after artificial insemination are markedly impaired. In these conditions, onset of estrus is delayed when compared to nonlactating control females (36.7 vs 33.9 hours after vaginal sponge withdrawal). However, ovulation takes place earlier during estrus (fig. 4), resulting in a similar time of ovulation after the end of the progestagen treatment. The $\mathrm{LH}$ surge is slightly delayed in lactating ewes, but this difference is not statistically significant. 
Cumulative percentage

of ewes in oestrus

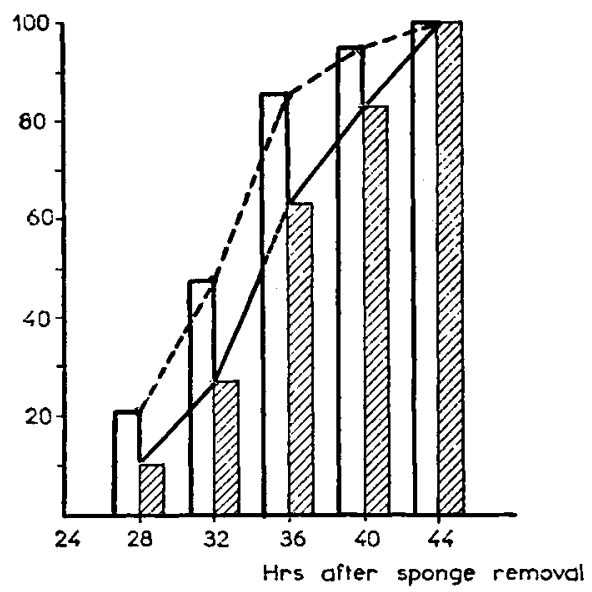

QZ7 Laciating ewes (750 UI PMSG)
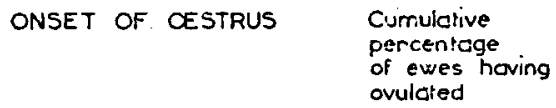

OVULATION

of ewes hoving

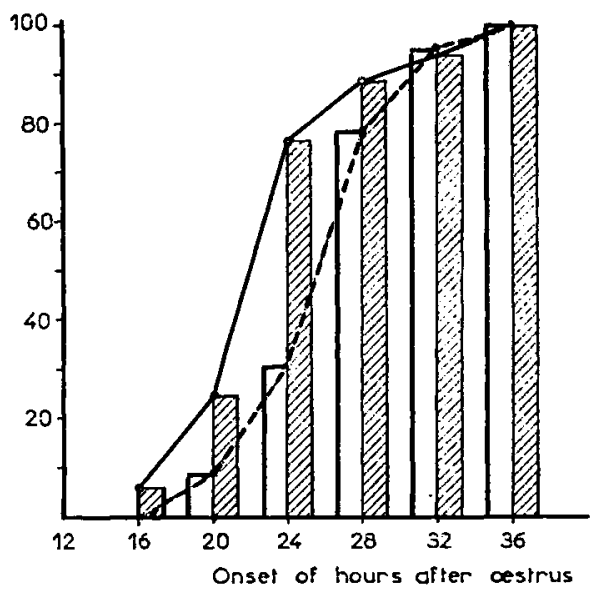

(From Cognié unpublished doto)

Fic. 4. - Iffect of lactation on oestrus and ovulation after FGA PMSG in ewes

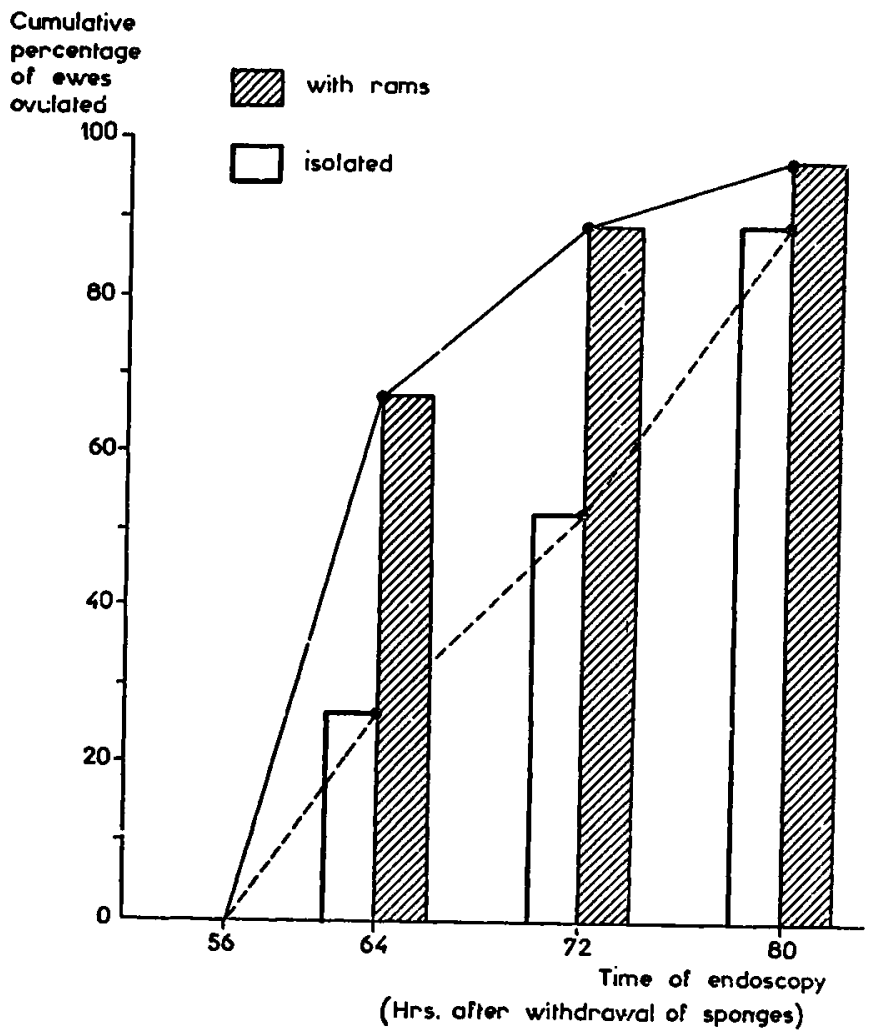

(From Lindsay et al. 1975)

Fic. 5. - The effect of the presence of the ram on the time of ovulation 


\section{F. - Effect of the presence of the male}

(LiNDSAY et al., I975, to be published)

The duration of sexual receptivity is reduced when the ram is permanently associated with the ewes during estrus (ZELTOBRUK and RAK ; I964; PARSONS and HUNTER, I967 ; FIETCHER and LINDSAY, I97I), but the action on the timing of ovulation remains questionable (VAN DER WESTHUIZEN et al., I970). The observation of females synchronized with FGA plus PMSG shows that the association with the male accelerates the process of ovulation by 8 hours when compared with females kept in total isolation, without any contact with the ram (fig. 5). The timing of the LH surge is similarly modified.

In the ovariectomized ewe, the LH surge induced by estrogen injection is accelerated by permanent presence of the male; the average interval between the injection of estradiol benzoate (40 micrograms intramuscularly) and the peak of plasma LH is $22.0 \pm x .05$ hours in the presence of the ram versus $28.55 \pm 0.98$ hours in the females kept in sexual isolation ( $\mathrm{P}$ inf. O.OI) (fig. 6) (SIGNORET, 1975, to be published).

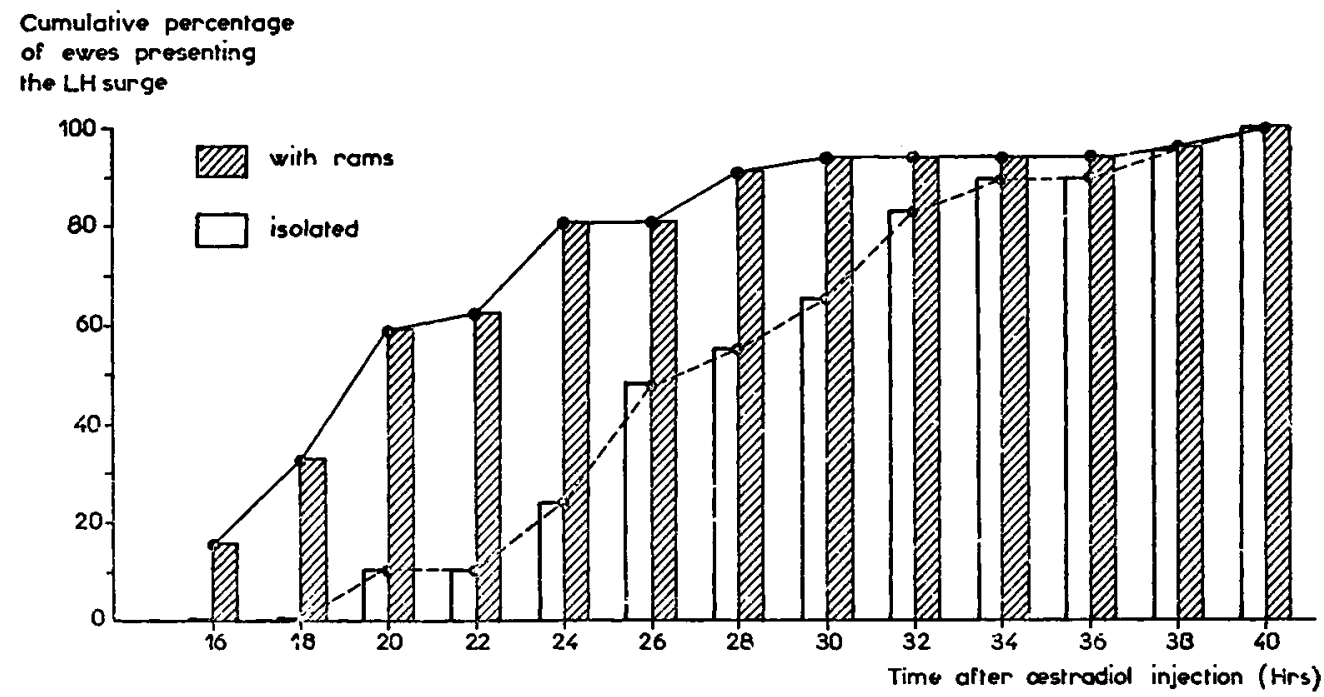

(From Signoret 1975)

Fig. 6. - Effect of the presence of rams on the LH surge in oziariectomiced eacs treated with progesterone and oestrogen

\section{II. - SOW}

The progestagens effective in ovulation control in sheep and cattle cannot be used in pig owing to the frequency of cystic ovaries after such a treatment. On the other hand, methallibure has been successfully employed in this species (PorGE, I964; GFRRITTS and Johnson, I964) (IOo mg/day orally for 20 days). The consequences of this treatment on the ovulation process will be analyzed. In the following 
studies, estrus was detected by presentation to an intact male at 6-hour intervals. The ovulations were observed by endoscopy and the results were analyzed after probit transformation

The number of ovulations occurring during one estrus period makes it necessary to determine not only the median time of ovulation, but the total duration of the process.

\section{A. - Time of ovulation during spontaneous estrus (du MesniL du Buisson et al., I970)}

In untreated control sows, ovulation usually begins 38.47 hours after the onset of behavioral estrus, and is completed at 42.27 hours. The entire process lasts 3.8 hours (fig. 7 ).

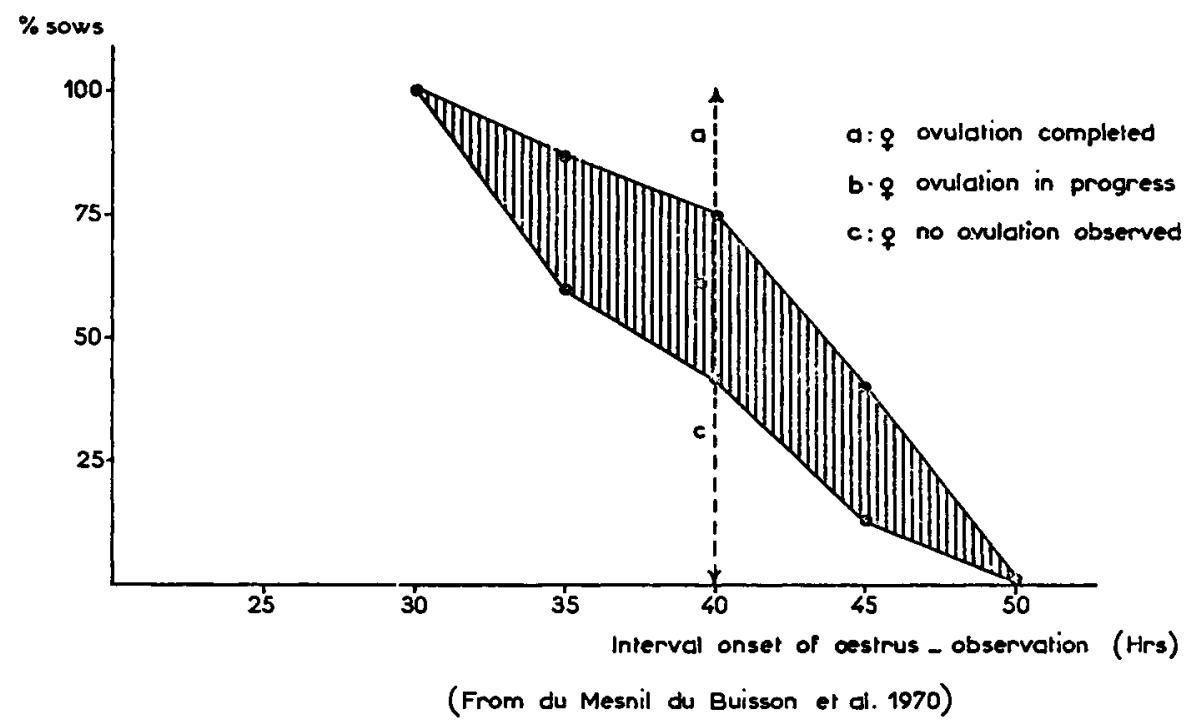

Iig. 7. - Evolution of the ovulation process in untreated sozes

B. - Effect of PMSG and HCG on the ovulation process (du MesniL, du Buisson et al., I97o)

When the experimental sows are treated with PMSG only (750 IU intramuscularly 24 hours after the last distribution of methallibure), the onset of ovulation is delayed by 3 hours, but the process is accelerated and lasts less than one hour. The median beginning and end of ovulation are observed 43.39 and 43.57 hours, respectively, after the onset of behavioral estrus (fig. 8). A further injection of HCG (500 IL intramuscularly 4 days after PMSG) does not change the process of ovulation when the sow is already in estrus at the time of injection (43.I9 hours after onset of estrus). However, if the experimental female is not sexually receptive at this moment, ovulation begins earlier in estrus (within 30 hours of onset of sexual receptivity), but the duration of the whole process is markedly increased (fig. 8). 


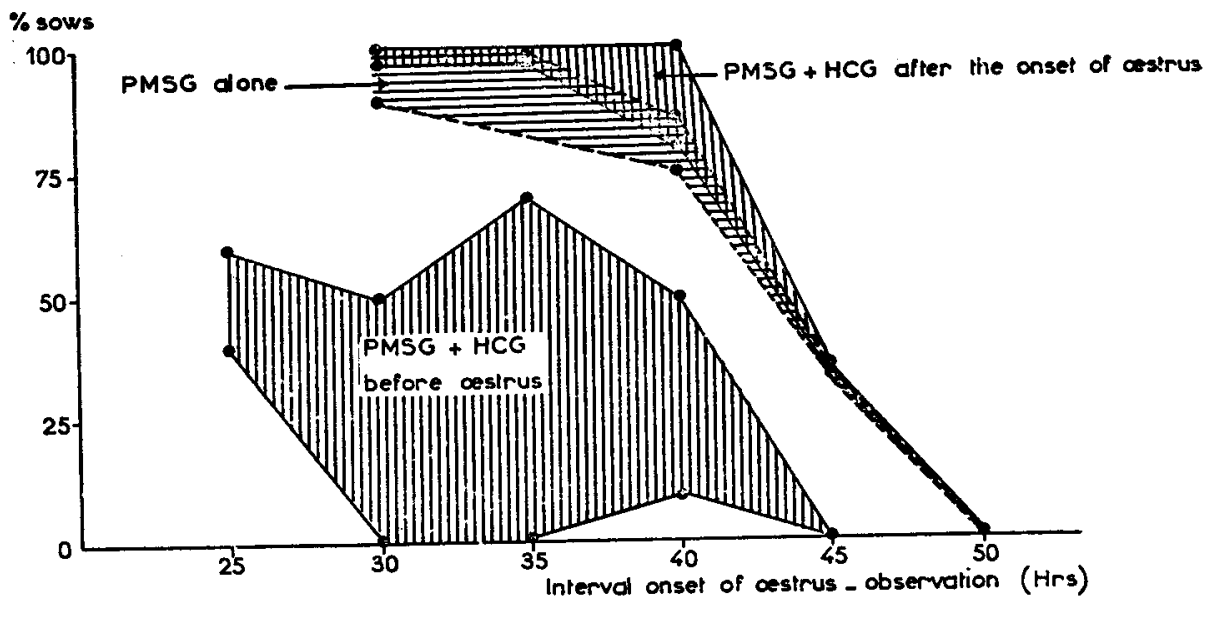

(From du Mesnil du Buisson et d. 1970)

FIC. 8. - Influence of PMSG and HCG on the ovulation in sows treated with methallibure

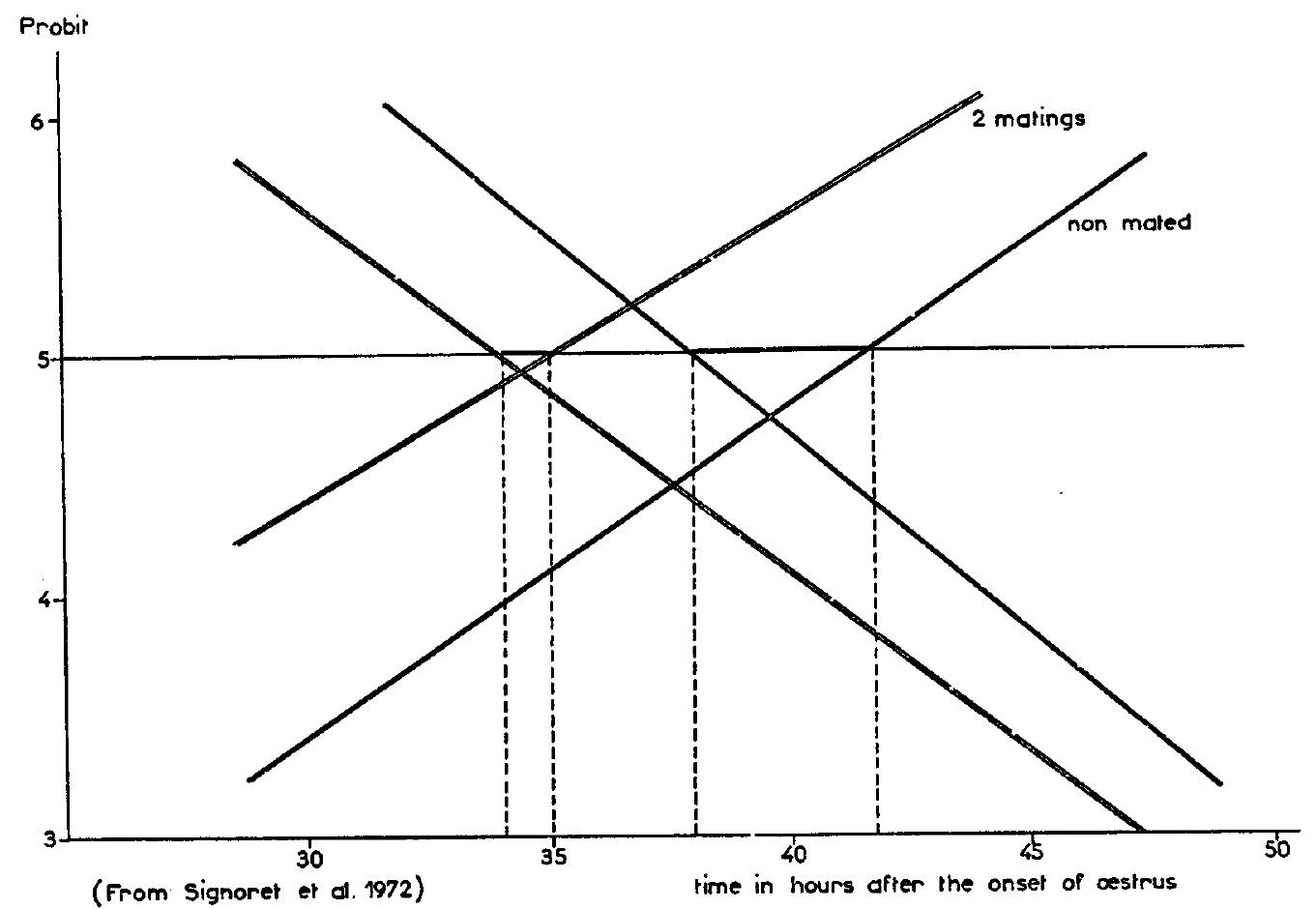

FIG. 9. - Effect of mating on the time and duration of ounlation in the son' 


\title{
C. - Effect of mating (SIGNoRET et al., I972)
}

When the sow is mated at the first sign of estrus and again 6 hours later, the median time for the onset of ovulation is 3.9 hours earlier than in unmated controls, and its duration is reduced by 2.8 hours (fig. 9). The median time for the onset and end of ovulation is 34 .I and 35.0 hours, respectively, after onset of estrus for the twice-mated females and 38.0 and $4 \mathrm{I} .8$ for the untreated controls.

\section{III. - CONCLUSIONS}

The hormonal control of the cycle results in minor changes in the timing of the ovulation process. Similarly, the consequences of the interaction of such treatment with seasonal and/or lactation anestrus are of limited importance. The timing of physiological events resulting in ovulation is modified by a maximum of 4 hours, and often less, for any of the criteria observed (ovulation, LH surge, onset of behavioral estrus after the end of hormonal treatment).

When compared to the limited action of hormonal treatment, the male influences markedly the timing of the ovulation process. Changes resulting from the presence of the male are at least twice as important as those induced by hormonal control of ovulation. Consequently, the important variations in the pregnancy rates obtained after estrus control, especially during seasonal or lactation anestrus, do not appear to be a result of modifications in the timing of the physiological events leading to ovulation. The more important changes due to the presence or the absence of the male are not associated with modifications in fertility.

In fact, results reviewed are of theoretical importance : the heterogeneity in response to PMSG in ewe and HCG in sow is of interest for the study of ovarian physiology. The presence of the male influence greatly affects the timing of ovulation and LH surge. A detailed study of this direct effect of external stimuli on neuroendocrine mechanisms would certainly result in a better knowledge of female sex physiology, and possibly in practical applications, for a better control of ovulation in the domestic species.

Colloque : Control of sexual cycles in domestic animals. October 27-30, 1974, Nouzilly.

\author{
RÉSUMÉ \\ DÉTERMINATION DU MOMENT DE L'OVULATION PAR RAPPORT \\ AU DÉBUT DE L'GSTRUS CHEZ LA BREBIS E'T LA TRUIE
}

Chez la Brebis, l'ovulation a lieu spontanément en moyenne 32,0 heures après le début observé de la réceptivité sexuelle ou œstrus. Ce moment n'est pas significativement modifié par le traitement de maitrise de l'ovulation comportant la mise en place d'éponges vaginales imprégnées de FGA. L'injection de PMSG accélère l'apparition de l'ostrus (3o heures contre 37 heures après la dépose des éponges de FGA), et celle de ]a décharge de $\mathrm{LH}(45,5$ contre 49 heures après la dépose des éponges). 
Pendant l'anoestrus saisonnier, l'état physiologique des femelles — lactation ou non - influence la réponse au FGA + PMSG : le début de l'oestrus est retardé chez les femelles allaitantes $(36,7$ heures contre 33,9 heures après la dépose des éponges imprégnées de FGA). On observe une tendance vers un retard de Ia décharge de LH tandis que les ovulations sont plus étalées que chez les témoins non en lactation.

La présence permanente du mâle accélère de 6-8 heures le moment de la décharge de LH et celui de l'ovulation, en même temps elle réduit la clurée de la réceptivité sexuelle.

Chez la Truie, l'ovulation débute en moyenne 38,5 et se termine 42,3 heures après le début de l'œstrus. Après traitement de Méthallibure et PMSG, l'ovulation est retardée, mais sa durée est réduite $(+3,3$ et 43,6 heures après le début de l'œstrus pour le début et la fin de l'ovulation).

Lorsque la Truie est accouplée à deux reprises dès les premiers signes de l'œstrus, l'ovulation est avancée et accélérée : elle débute 34 , I heures et se termine 35, o heures après le début de l'oestrus. La présence continue du mâle réduit la durée de la réceptivité sexuelle.

\section{REFERENCES}

Cognie Y, Mariana J. C., Thimonier J., ig7o. Étude du moment d'ovulation chez la Brebis normale ou traitée par un progestagène associé ou non à une injection de PMSG. Ann. Biol. anim. Bioch. Biophys., 10, I5-24.

Fletcher I. C., Lindsay D. R., I97I. Effect of rams on the duration of oestrous behaviour in ewes. $J$. Reprod. Fert., 25, 253-259.

Finner D. J., 1962. Probit analysis, znd ed., Cambridge University Press.

Gerrits R. J., Johnson L. A., I964. The effect of an orally administered non steroids on oestrus and ovulation and fertility in gilts. Proc. Vth Int. Cong. Anim. Reprod. Artif. Insem. Trento, 3, 455-459.

Lindsay D. R., Cognie Y., Pelietier J., Signoret J. P., I975. The influence of the presence of rams on the timing of ovulation and discharge of $\mathrm{LH}$ in ewes. Physiol. Behav. (under press).

Mauleox P., Daczier L., I965. Variations de durée de l'anœstrus de lactation chez les brebis de race Ile-de-France. Ann. Biol. anim. Bioch. Biophys., 5, I3I-I43.

du Mesnil du Buisson F., Mauleon P., Locatelli A., Mariana J. C., ig7o. Modification du moment et de l'étalement des ovulations après maitrise du cycle sexuel de la Truie. In : L'inhibition de l'ovilation, Masson éd., 225-234.

Parsons S. D., Henter G. L., 1967. Effect of the ram on duration of oestrus in the ewe. J. Reprod. Fert., 14, 6I-70.

Pelletier J., liand G., Dolais J., Rosselin G., ig68 b. Dosage radioimmunologique de l'hormone lutéinisante plasmatique chez le Mouton. Mise au point de la technique de dosage. C.R.Acad. Sci., Paris, 266, 2291-2294.

Pelletier J., Thimonier J., rg69. Étude de la décharge ovulante par dosage radioimmunologique de la LH plasmatique, chez la Brebis normale ou traitée par un progestagène. C. R. Acad. Sci. Paris, 268, $573-576$.

Polge C., 1965. Effective synchronisation of oestrus in pigs after treatment with ICI-33828. Vet. Rec., 7y, $232-236$.

Robinson T. J., I965. Use of progestagene impregnated sponges inserted intravaginally of subcutaneously for the control of the oestrous cycle in the sheep. Nature, 206, 39.4I.

Signoret J. P., du Mesnil du Buisson F., Mauleon P., I972. Effect of mating on the onset and duration of ovulation in the sow. J. Reprod. Fert., 31, 327-330.

Signoret J. P., I975. Influence of the presence of rams on the LH surge after oestradiol benzoate injection in ovariectomized ewes. $J$. Endocr., 64 (under press).

Thimonifr J., Mauleon P., ig69. Variations saisonnières du comportement d'œstrus et des activités ovarienne et hypophysaire chez les Ovins. Ann. Biol. anim. Bioch. Biophys,, 9, 233-25o.

Tumonier J., Macleon P., Cognie Y., Ortavant R., r968. Déclenchement de l'oestrus et obtention de la gestation pendant l'anœstrus post-partum chez les brebis à l'aide d'éponges vaginales imprégnées d'acétate de fluorogestone. Ann. Zootech., 17, 257-273.

Van der Westhuysen J. M., Van Niekerk C., Hunter G. L., I97o. Duration of oestrus and time of ovulation in sheep : effect of synchronization, season and ram. Agroanimalia, 2, I3 $3^{\mathrm{I}-3^{8}}$.

Zhiztobruk N. A., Rak L. A., I964. Stimulation neuro-sexuelle de la fonction reproductrice des brebis (Russe). Ovtsevodstvo, 10 (8) 8-I I. 